\title{
Sustainable Marketing: A Marketing Revolution or A Research Fad
}

\author{
Wael Kortam \\ Business Administration Department, \\ Faculty of Commerce, Cairo University, Egypt \\ Abeer A. Mahrous \\ Business Administration Department, \\ Faculty of Commerce, Cairo University, Egypt
}

\begin{abstract}
This paper aims to demonstrate that while marketing and sustainability might seem to be as different as "A Polar Bear and A Bengal Tiger", there is growing evidence that the two disciplines have something to offer each other and the universe. With a view toward gaining this synergy, this research proposes that a lasting sustainability marketing as an academic discipline and managerial practice must aim deliberately and thoroughly to reassure itself as an outstanding potential for a marketing revolution and distance itself away from the danger of ending up as a quick-shot research fad. Conclusively, a sustainability marketing revolution can be sparkled and kept alive and a sustainability marketing research fad can be avoided and reversed through a number of highly recommended visible venues of marketing research and managerial pursuits.
\end{abstract}

\section{INTRODUCTION: WHAT IS SUSTAINABLE MARKETING? AND WHY IT'S IMPORTANT NOW?}

Sustainable marketing is part of the sustainable development field, a field that is defined by the Brundtland commission of the World Commission as "development that meets the needs of the present without compromising the ability of future generations to meet their own needs". It aims at marinating productivity and efficiency through replacing resources with other resources that have greater value in order to avoid harming the ecosystems or degrading the natural resources (Marzouk and Mahrous, 2017). This is why sustainable marketing is considered a part of the broader sustainable development field (Shazly and Mahrous, 2017).

Figure 1: Foundational Principals of Sustainable Marketing

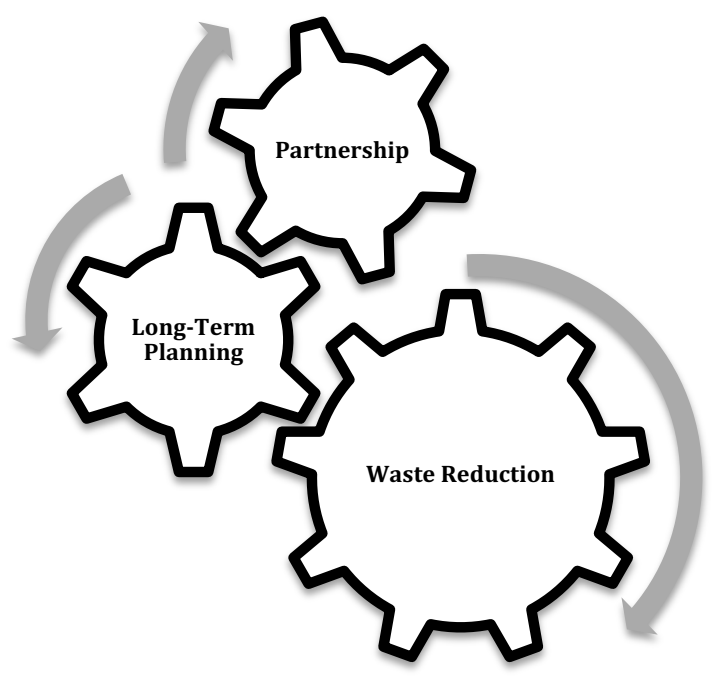

Source: www.enotes.com 
The issues of concern to sustainability marketing scholars range a lone a broad spectrum, stretching from marketing materials reduction, eliminating unnecessary physical channels to the use of Trans-fat and toxic food ingredients (Newton, 2018). Sustainable marketing rests on three pillars as depicted in figure 1. First, sustainable marketing encourages reducing waste through decreasing the amount of materials used in promotion and packaging and promoting the reuse of carryon packages and developing more degradable package and promotional solutions. Second, sustainable marketing also encourages partnering with customers instead of selling to them; through the use of social networking sites companies can rely on lead users and highly involved customer for cross-promotion and sharing information. Finally, one of the effective ways to apply sustainable marketing is to encourage long-term planning to protect the advertising and promotion from fluctuations in demand and hence efficiently minimize advertising prices (Hardison, 2010).

Despite the fact that many people and politicians still debate about climate change and global warming and the conflict between economic growth and sustainable development, the perception that it's "Now or Never" or "The last chance to preserve the earth as a human habitat" is accumulating and rising. This wave began with the social movement in the $1970 \mathrm{~s}$ and early 1980s. It resulted in a rising wave of environmentally conscious consumers. Individuals like to deal or buy from companies that are environmentally conscious. Additionally, environmental lobbyists have succeeded to push governments and regulators in many developed and developing countries to business regulations and economic indicators to reward environmentally conscious organizations. All of this has caught the attention of business and marketing scholars to address a number of issues related to explore consumers' conservative behavior and sustainable purchasing decisions, and organizations' motives to pursue sustainable marketing strategies among other topics.

To this end, this paper aims at investigating sustainable marketing from a theoretical perspective to synthesize the current literature on sustainable marketing and advocate for the way forward on sustainable marketing research thinking.

\section{Sustainability and Marketing - The Controversy of Contradiction and Reciprocity}

In so many ways, marketing is often seen as the antithesis of the concept of sustainability. Marketing is seen by many as one of the principal drivers of consumption, while sustainability seeks to enable all people throughout the world to satisfy their basic needs and enjoy a better quality of life without compromising the quality of life of future generations. There is however, growing interest in the relationship between marketing and sustainability (Jones et al, 2008 and Gordon et al, 2011).

The sigma sustainability marketing guide, designed to help businesses develop strategies to market the benefits their approach to sustainability to their customer bases and to help their sustainability managers and leaders gain a shared understanding of their respective areas of expertise. This guide disputes the argument that sustainability and marketing are extreme ends that can never meet. On the contrary, it argues that sustainability and marketing have much to offer to each other in an evidently reciprocal and synergistic fashion (Jones et al, 2008 and Upton, 2016)

\section{Sustainability-To-Marketing Back and Forth Pathway}

A growing number of businesses are looking to recognize the role of sustainability as an integral component of their business strategy. However, the Chartered Institute of Marketing has found that marketing teams lead on campaigns and communications but not on business strategy. This is mainly because marketing does not lie at the strategic core of 
sustainable development and that marketing teams are not assuming a critical role in driving forward the development of sustainable products and services. Research suggests that marketing contemporarily has a secondary, rather than a primary role in fulfilling sustainability agendas within many businesses (Kumar et al, 2012).

Having said that, it is important to acknowledge that there is a growing stream of literature on "sustainability marketing" which has been defined as "creating, producing and delivering sustainable solutions with higher net sustainable value whilst continuously satisfying customers and other stakeholders". Ideally, the goals are to systematically embed sustainability within a business strategy throughout the supply chain from new product and service development to after-sale services (Belz and Peattie, 2009).

More specifically, one of the most obvious links between marketing and sustainability is the way in which a growing number of businesses are looking to emphasize their commitment to sustainability in an attempt to help to differentiate themselves from their competitors and to enhance their brand equity and corporate image. So, the accent is integrating sustainability thinking into the essence of the core brand. In pursuing such a strategy, it is important that businesses take account of all the contact points between the brand and the customer. There are also issues relating to internal marketing or more particularly with getting sustainability accepted throughout an organization and in engaging all employees in the sustainability debate. In order for a business to build its sustainability credentials, an all pervading culture needs to be deployed for staff to recognize opportunities and to deal with them. Furthermore, it is argued that where the concept of sustainability is taken on board by employees which should be expected to lead them to have a greater sense of loyalty and pride in the organization and that this, in turn, can prove to be a valuable "sales asset" when communicating with customers (Blez and Peattie, 2010, Jones et al, 2009 and Kumar et al, 2012).

Nevertheless, there is little evidence that marketers build on these benefits when projecting an organization's sustainability in the public domain. A growing number of organizations are encouraging their employees to participate in community programs often aiding them in enhancing their understanding of sustainability challenges within the local environment. At the same time, it is important to recognize that where employees are working under pressure to meet demanding performance and financial targets, promoting sustainability may be quickly and conveniently ignored (Upton, 2016 and Elalfy and Kortam, 2014).

\section{Marketing-To-Sustainability Back and Forth Pathway}

In pinpointing the contributions of marketing to sustainability, research attention is focused on the role of marketing in understanding and changing customer behavior and more generally in influencing attitudes and beliefs. As such, marketing can be viewed to recognize the key role of customers as decision makers in moving towards sustainability, for example in reducing carbon dioxide emissions, recycling increasing volumes of waste, supporting fair trade initiatives and adopting healthier lifestyles( Elalfy and Kortam, 2014, Kumar et al 2012 and Kortam and Gad, 2014).

Studying the current buying processes of green customers can provide important insights into helping to preach for sustainable buying behavior and to understand the reality of trying to operationalize green or ethical customer values in terms of concrete purchases. More specifically, while those customers are generally predisposed to buy sustainable 
products, their buying processes are also constrained by a range of more conventional factors including price, brand and availability and that in order to increase sustainable patterns of consumption, it is vital to know more about how customers arrive at their buying decisions (Upton, 2016 and Jones et al, 2008).

Marketing research argues that while green customers aim to translate their sustainability values into purchasing standards, such as energy efficiency or local sourcing, decisions concerning actual buying processes also incorporate more conventional factors which effectively compete with sustainability criteria. According to one study, the significant complexity of decision making led green customers to complain that sustainable shopping was "hard work" and that sustainability criteria were likely to be abandoned. More positively, it is easier to encourage sustainability buying processes in Fast Moving Consumer Goods (FMCG), such as food and pharmaceuticals, where regular shopping allows habits to be formed and maintained rather than it is for the occasional purchase of large items like a fridge, an automobile or a real estate (Kortam and Gad, 2014).

A focus on changing buying behaviors is one of the key drivers to boost sustainability consumption. This approach is partially rooted in the recognition (recently supported by empirical evidence on public attitudes and behaviors towards the environment, of an often sharp discontinuity between awareness of the environmental impacts of a particular set of behaviors and a willingness to change personal behavior to reduce such impacts. Empirical marketing research focused on behavioral change in terms of establishing the link between environmental practices and everyday behaviors targeting policy implications for specific life-style-based market segments and building the potential for change of customers' buying behaviors and consequential action outputs (Huml, 2006 and Upton, 2016).

More generally, there is the argument that by harnessing marketing creativity and imagination that is often viewed to be one of the featured hallmarks of marketing, it may be possible to move towards a more sustainable future.

\section{Sustainability and Marketing - The Proclaimed Synergy}

While marketing and sustainability might seem to be as different as " A Polar Bear and A Bengal Tiger", there is growing evidence that the two disciplines have something to offer each other and the universe.

On the one hand, an increasing number of businesses publicly claim to be committed to an all-embracing definition of sustainable development and A Solution/Information/Value/Access (SIVA) mix of sustainable goods and services. Having said that, many of the sustainability commitments claimed by businesses can be interpreted as being driven by business imperatives. Thus, for example, while many of the environmental initiatives currently being made by a number of the UK's prominent retailers are designed to reduce energy, water consumption and waste emissions, they also reduce costs significantly. On the other hand, there are claims that marketing offers important ways of changing buying behaviors and influencing attitudes and beliefs of customers. However, it remains to be seen over a relatively extended time span, whether marketing has the power and inclination to promote the sort of radical lifestyle changes that a truly sustainable future demands (Gordon et al, 2011, Kumar et al, 2012 and Kortam and Gad, 2014). 


\section{CRITIQUE AND NOVELTY OF SUSTAINABILITY MARKETING THEORY AND PRACTICE - THE PROMISE OF A MARKETING REVOLUTION}

Green marketing, cause-related marketing, ethical marketing, sustainability marketing, mission marketing, sustainability communications, social brand, purpose- driven brands and sustainable brands are just some of the new business and marketing terms entering into mainstream adoption and creation onto the minds of many -a sure pathway to indicate that conventional marketing ought to give way to a new era of sustainable marketing with special emphasis on sustainable branding is in and it is here to stay. But as the business terminology develops, and with no clear conceptualization or clear delineation between the different terms being coined, it may also appear to be quite a semantic jungle. It is not always clear cut as to what the terminology and evolving relationships mean and look like in theory and practice. How exactly marketing research and management are moving from a traditional form of marketing to a more holistic form of marketing which encompasses the wider business purposes, sustainability and corporate social responsibility (Upton, 2016, Belz and Peattie, 2009, Smith, 2009 and Kumar 2012).

Embedding sustainability into marketing thought and actions has - and is - being developed in numerous ways, depending on the individual researcher(s) and his/her agenda(s) and the individual business and its marketing offering(s). The research projects, business strategies and activations implemented range from the eco-labeling of products throughout to fully integrated marketing and sustainability strategies and systems which emit from a central business core, and are intermingled into every gene of business (Kumar, 2012, Gordon et al, 2011, El-Alfy and Kortam, 2014).

Marketing research have identified some highly-profiled approaches that marketin scholars and entrepreneurs are currently using to address and drive this evolving relationship between sustainability and marketing and reach out to a newly conscious customer with a different mindset, comprising the following areas: (Blez and Peatties, 2009 and 2010, Gordon et al, 2011, Upton 2016 and Smith, 2009)

1- On-pack eco credentials.

2- Cause-related marketing and promotion.

3- "Behind the brand" expose.

4- Campaigning for customer values and behavior change.

5- Changing the status quo and ideology of marketing as a science.

6- Driven-by-core-business-purpose-marketing.

The different marketing research methodologies and business strategies mentioned above, all manifest how the relationship between marketing and sustainability is evolving, and how the two disciplines and business ideologies, can work in synergy together to communicate in a genuine and innovative way to customers, entrepreneurs and researchers alike.

By the same token, communicating this message in a crystal clear way which empowers customers to make better buying decisions based on their own values, makes it easier for them to make responsible and sustainable consumption choices. As the relationship between sustainability and marketing continues to evolve, it will be interesting to see which marketing research methodologies, business strategies and marketing campaigns stand the tests of rigor, applicability and time, and which research frontiers, strategic options and tactics arise in the foreseeable future as scholars, entrepreneurs and customers become ever more knowledgeable, conscious and demanding of business entities (Kortam and Gad, 2014). 
Time has witnessed the different phases of marketing strategy. Out of which, sustainability is the key issue which has emerged in marketing strategy over the time. In earlier phase of the 1970's, ecological issues have emerged as a new paradigm in marketing strategy. Then in the next decade, social issues picked up the lime light and paced up alongside ecology (Kumar et al, 2012 and Belz and Peattie, 2009).

Re-assessment of the issues resulted in evolution of green or environmental issues in marketing strategy and recently the sustainability in marketing strategy has become the focus of attention of strategic marketing research as a real potential of marketing revolution. Therefore, the agenda for future research in sustainability marketing should be argued to cover (Gordon et al, 2011):

1- Reviewing and comprehending concepts of marketing strategy as they adapt to sustainability principles.

2- Examining evolution of sustainability in marketing strategy.

3- Envisaging a visionary future of sustainability in research and practice of strategic marketing.

\section{Sustainability Marketing Myopia - The Danger of A Research Fad}

Sustainability marketing myopia is a term used in sustainability marketing literature to refer to a distortion stemming from the overemphasis of socio-environmental attributes of a sustainable product or service at the expenses of customer benefits and values. The idea of sustainability marketing myopia is rooted into environmental marketing myopia theory, as well as green marketing myopia (Ottman, 2006).

The marketing myopia theory was originally proposed in 1960 by American Management Theorist Theodore Levitt. According to Levitt, marketers should not overemphasize the company potential and product attributes at the expenses of market needs; catering for market needs should receive first priority. Marketing myopia has been highly influential in the formation of modern marketing theory, and was heeded by marketers to such an extent that some authors now speak of a "new marketing myopia" stemming from too narrow a focus on customers to the exclusion of other stakeholders (Levitt, 1960 and Smith, 2009).

In order to be successful, green marketing must fulfill two objectives; improved environmental quality and customer satisfaction. Misjudging either or overriding the former at the expense of the latter can be defined as green marketing myopia. The marketing discipline has long argued that innovation must consider an intimate understanding of the customer and a close look at green marketing thought and practice over time reveals that green products must be positioned on a customer value sought by target market segments. Apart from offering environmental benefits that do not meet customer preferences, green marketing myopia can also occur when green products fail to provide credible substantial environmental benefits (Smith, 2009 and Ottman, 2006).

Just as an excessive focus on product attributes generates marketing myopia, and just as a single-minded focus on customers results in "new marketing myopia", in both green and sustainability marketing, an unbalanced strategy neglecting one aspect (namely; product attributes) is detrimental to the effectiveness of the marketing process. However, it is important to note that sustainability marketing myopia differs from green marketing myopia in that the former follows a broader approach to the marketing myopia issue, taking into account the social attributes of a product as well as the environmental ones. At the same time, sustainability marketing myopia encompasses sustainable services and productrelated services, not products alone (Smith, 2009). 
Unfortunately, all these sources and dimensions of sustainability marketing myopia created a mainstream of research fads in sustainability marketing literature, limiting the scope and impact of marketing innovation in adopting conventional marketing research methodologies to tackle sustainability issues just to pretend implicitly that marketing is out and about to change for sustainability cause and seek to appease sustainability customers by looking faithful to their responsible demand.

\section{Eruption of Sustainability Marketing - Sparkling a Revolution and Deflecting a Research Fad}

Conclusively, a sustainability marketing revolution can be sparkled and kept alive and a sustainability marketing research fad can be avoided and reversed.

First, marketing research and management should strive to identify and stress the inherent customer values (efficiency and cost effectiveness, health and safety, convenience, symbolism and status) of the socio-ecological features of the product. In other words, marketing scholars and entrepreneurs should highlight the personal customer benefits stemming from the socio-ecological features of the product (Smith, 2009, Gordon et al, 2011, Kumar, 2012 and Upton, 2016).

Second, marketing research and management ought to find effective ways to align the socioecological attributes with core benefits of the product to create "motive alliances". Core benefits of the product can comprise functionality, performance, design, durability, taste, freshness, uniqueness, aesthetics, and fashion. "Motive Alliances" are the associations of such core benefits with the relevant socio-ecological attributes embedded in the product; as a wrap up bundling (Upton, 2016 and Kumar et al, 2012).

Third, a lasting sustainability marketing as an academic discipline and managerial practice must aim deliberately and thoroughly to reassure itself as an outstanding potential for a marketing revolution and distance itself away from the danger of ending up as a quickshot research fad. This research strongly recommends that marketing research and management must deliberately and creatively seek to adapt the following principles and tools of sustainability into marketing creed and actions to make itself a truly missionary and ideologically responsible business undertaking: 1) welfare of future generations, 2) cradle-tocradle businesses, 3) preservation of natural resources, 4) economics of love, 5)social innovation, 6) social entrepreneurship and 7) Corporate Social Responsibility. (Gad and Kortam, 2014 and Huml, 2006)

Fourth, Equally crucial, sustainability marketing research and management must equip itself with the following marketing powerful philosophies and orientations to make itself a truly valorized and perpetuated business undertaking: 1) customer- mindedness and wellbeing, 2) profitability orientation, 3) Knowledge-intensive, 4) customer education and manipulation, 5) effectiveness-focused, 6) growth-driven, and

7) blended positivistic/normative/interdisciplinary methodologies. (El-Alfy and Kortam, 2014, Gordon et al, 2011 and Kortam and Gad, 2014).

Fifth, as far as sustainability marketing theory and policy are concerned, action research, qualitative research (with special reference to grounded theory and protocol analysis) (Mahrous et al., 2010) and multidimensional/multi-phased quantitative research can be argued to provide the proper forum for this revolutionizing initiative and a safeguard against its very risky pitfall into a research fad. 
As a way forward, to deflect the sustainable marketing research fad, this paper argues that the stakeholder theory is an appropriate theoretical lens to address and resolve the controversies surrounding sustainable marketing and overcoming the conflict between organizations and consumers when applying sustainable marketing.

Stakeholder theory argues that stakeholders are all groups on which the organization is dependent for its continued survival (Stanford Research Institute, 1963). Also, Freeman and Reed (1983) added that stakeholders are all individuals and/or groups whom can affect and/or be affected by the achievement of an organization' objectives. In light of this, the stakeholders of each organization must be determined and managed in a way to capitalize on sustainable marketing strategies and/or practices (Mahrous and Hassan, 2016). In specific, when developing sustainable business and/or marketing strategies organizations must determine "Who and What really counts?" According to the aforementioned discussion not all parties' interests can be satisfied by sustainable marketing practices. Especially there is no apparent ceiling to sustainability development aspirations to which organizational strategies should aim at reaching. To this end, the following figure shows the various stakeholders related to sustainable business practices. We argue that instead of the existence or nonexistence of the interests in specific stakeholder group in the target audience's interests that must be satisfied by the business strategies, organizations can weigh their impact on its operations and hence include their objectives with this weight in the organizational objectives that must be met. As a result, the outcomes of the sustainable business strategies will be balanced and profitable in short and long-terms.

\section{Figure 2: Stakeholders of Sustainable Marketing}

\begin{tabular}{|c|c|c|}
\hline $\begin{array}{l}\text { 6 Key Stakeholders } \\
\text { 1. Local communities } \\
\text { 2. Diversity } \\
\text { 3. Treatment of employees } \\
\text { 4. The natural environment } \\
\text { 5. Product safety and quality } \\
\text { 6. Corporate governance }\end{array}$ & $\begin{array}{c}\text { Each variable } \\
\text { can be socially } \\
\text { strong or weak }\end{array}$ & $\begin{array}{l}\text { - Quantitative } \\
\text { indicators of } \\
\text { corporate } \\
\text { performance } \\
\text { - Qualitative indicators } \\
\text { of corporate } \\
\text { performance }\end{array}$ \\
\hline
\end{tabular}

\section{CONCLUDING REMARKS}

Sustainable marketing research is relatively a new concept in business and marketing literature, but it is already proving to be a game changer. The paper focused on synthesizing the literature on sustainable marketing. From an environmental and social sustainability perspective, the paper indicated that sustainable marketing research focused mainly on identifying business and marketing strategies and/or tactics that seek to meet the needs of current generations without messing up the needs of future generations. Furthermore, it pointed out the fact that sustainability has become a key concept to both organizations and marketing researchers. Scholars in both sustainable development research and sustainable marketing research discussed consumers' behavioral responses related to debate about climate change, world's population growth, and the effect of marketing activities. In addition, regulators and NGOs have actively issued regulations and indices to encourage for-profit organizations to adopt business strategies in line with sustainable development goals. Nevertheless, there is still much to be done in terms of resolving the controversy between the heavenly optimistic sustainable marketing implications advocated by marketing scholars and lobbyists and the marketing realities on the ground. The paper discussed that despite the urging need and somewhat realized importance of sustainable marketing, the social and 
financial implications of sustainable marketing have not been efficiently manifested efficiently on either the business or the consumer levels.

Therefore, the researchers advocate for a new theoretical lens to study and apply sustainable marketing in order to overcome the previously mentioned controversies. Previous research on sustainable development argued that key organizational theories are appropriate for marketing research on sustainability such as: transaction cost economics, agency theory, institutional theory, organizational ecology, resource dependence theory, resource-based view of the firm, social network theory, and signaling theory. However, this paper argues that the use of stakeholder theory is a more appropriate theoretical lens to address and resolve the controversies surrounding sustainable marketing and overcoming the conflict between organizations and consumers when applying sustainable marketing.

\section{References}

Belz, F.M., and Peattie, K., (2009), "Sustainability Marketing: A Global Perspective", (Chichester: Wiley).

Belz, F.M., and Peattie, K., (2010). The Eight C's of Sustainability Branding, (London: Blackwell).

Connelly, B. L., Ketchen, D. J., \& Slater, S. F. (2011). Toward a "theoretical toolbox" for sustainability research in marketing. Journal of the Academy of Marketing Science, 39(1), 86-100

El-Alfy, Shahira and Kortam, Wael, (2014), Exploring Environmental Sustainability Performance in The Cellular Telecommunications Industry in Egypt", Proceedings of the $28^{\text {th }}$ Enviroinfo Conference, University of Oldenburg, Germany.

Gordon, Ross, Carrigan, Marylyn, and Hastings, Gerard, (2011), " A Framework For Sustainable Marketing", Marketing Theory, Vol.11, No.2, pp.143-163.

Huml, P., (2006), Fair Trade: Economics of Love, (New York: Trade Forum).

Hardison, K. (29 April 2010) "What is the meaning of the sustainable marketing and how does such an approach lead to better relationships with customers?" eNotes, Retrieved at, https://www.enotes.com/homeworkhelp/what-meaning-sustainable-marketing-how-such-an-163469. Accessed 25 September. 2018.

Kortam, Wael and Gad, Ghada, (2014), "Knowledge-Based Marketing For Social Innovation", Journal of American Science, Vol.10, No.2, pp.143-147.

Kumar, Vinod, Rahman, Zillur, Kazmi, A.A., and Goyal, Praveen, (2012), "Evolution of Sustainability as Marketing Strategy: Beginning of a New Era", Procedia- Social and Behavioral Sciences, Vol.37, No.12/13, pp.482-489.

Jones, Peter, Clarke-Hill, Colin, Comfort, Daphne and Hillier, David, (2008), "Marketing and Sustainability", Marketing Intelligence and Planning, Vol.26, No.2, pp.122-133.

Mahrous, A., Kortam, W., \& Anis, A. (2010). The role of students' expectations and evaluations in the learning process and market orientation of business schools in Egypt. In British Academy of Marketing Conference, Coventry Business School, Coventry, UK (pp.1-7).

Mahrous, A. A., \& Hassan, S. S. (2017). Achieving superior customer experience: An investigation of multichannel choices in the travel and tourism industry of an emerging market. Journal of Travel Research, 56(8), 1049-1064.

Marzouk, O., \& Mahrous, A. (April 2017). An Exploratory Study On Energy And Water Sustainable Consumption Behaviors Of Rural Consumers In Egypt. Faculty of Commerce, Cairo University Annual Conference, Cairo, Egypt, 2017.

Newton, K. (2018). What Is Sustainable Marketing? - Definition \& Concepts, Study.com, retrieved at https://study.com/academy/lesson/what-is-sustainable-marketing-definition-concepts.html. Accessed at 7 November 2018.

Levitt, Theodore, (1960), "Marketing Myopia", Harvard Business Review, March- April.

Ottman, J., Stafford, E., and Hartman, C., (2006), "Avoiding Green Marketing Myopia", Environment, Vol.48, No.5, pp.22-36.

Shazly, R., \& Mahrous, A. (April 2017). A qualitative investigation of the factors associated with attitude toward causal-related marketing campaigns in services industries in Egypt. 
Smith, N., Drumwright, M., and Gentlie, M.C., (2009), "The New Marketing Myopia", INSEAD Working Paper No. 2009/08/INSEAD Social Innovation Centre.

Upton, Emma, (2016), " The Evolving Relationship Between Sustainability and Marketing", Corporate Citizenship Briefing, News and Analysis on Responsible and Sustainable Business, Los Angeles. 